\title{
FOOD PROHIBITION IN ISLAM: A STEP TOWARDS GOOD HEALTH
}

\author{
ADIGUN WASILAT FAYOKEMI (Ph.D) \\ Department of Islamic Studies \\ School of Arts and Social Sciences \\ College of Education Ikere, Nigeria \\ adigunwasilat@gmail.com
}

DOI: $10.29322 /$ IJSRP.10.02.2020.p9814

http://dx.doi.org/10.29322/IJSRP.10.02.2020.p9814

\begin{abstract}
Food intake undoubtedly has the greatest effect on human health. In many parts of the world, the problems of drug abuse and bad food consumption have deteriorated people's health to the extent that, reports revealed that, many have been afflicted with no greater calamity than alcohol. In Nigeria, many illnesses such as mental disorders, delirium tremens, nervous breakdown, digestive ailments as well as developmental and social problems like violent, accident, suicides, homicides, bankruptcies, broken homes are associated with alcoholic consumption. However, food prohibition in Islam aims at purifying human body and soul as well as giving guidance to what man can eat that will improve his health and save him from difficulties. This paper therefore, discusses foods that are prohibited in Islam based on the Qur'an and hadith which serve as the first primary source of Islamic law. It concludes that, the kind of food eating has a decisive effect on the soul and the entire body and therefore recommend that Muslims should follow the dictates of Islam regarding food prohibitions in order to live a healthy life.
\end{abstract}

Key words: Food, Health, Prohibition, Islam,

\section{Introduction}

Food is very important for the survival of human life. One of Islam's symmetry is that, it acknowledges the importance of food consumption in nourishing the system while allowing the good and beneficial type of foods, it forbids those that are harmful and injurious to health. Islamic dietary rules are excellent ways to avoid certain diseases. Islam as a complete way of life provides numerous guidelines on how mankind can interact with food. These guidelines are found in the Qur'an- Divine message of Allah and Hadith- The recorded way of life of Prophet Muhammad (SAW). For instance, in the following verses, Allah addresses mankind generally and Muslims in particular thus:

O mankind! Eat of what is permissible and good on earth and do not follow the footsteps of Satan; truly he is an open adversary to you. (Qur'an 2:168); O you who believe! Eat of the good things that We have provided for you, and be thankful to Allah if it is He alone whom you worship. Indeed, what He has forbidden to you is the flesh of dead animals and blood and the flesh of swine, and that which has been sacrificed to anyone other than Allah. But if one is compelled by necessity, neither craving (it) nor transgressing, there is no sin on him; indeed, Allah is Forgiving, Merciful (Qur'an 2: 172-173); Forbidden to you are the flesh of dead animals and blood and the flesh of swine, and that which has been dedicated to any other than Allah, and that which has been killed by strangling or by beating or by falling or by being gored, and that which has been (partly) eaten by a wild beast except that which you make lawful by slaughtering (before its death), and that which has been sacrificed to idols (Qur'an 5:3).

In another verse thus:

The ask you (O Muhammad) what is lawful for them (as food) Say: "Lawful to you are At-Tayyibat \{all kinds of Halal (lawful-good) foods which Allah has made lawful (meat of slaughtered eatable animals, milk products, fats, vegetables and 
fruits) $\}$. And those beasts and birds of prey which you have trained as hounds, training and teaching them (to catch) in the manner as directed to you by Allah; so eat of what they catch for you, but pronounce the Name of Allah over it, and fear Allah. Verily, Allah is Swift in reckoning. Made lawful to you this day are At-tayyibat \{all kinds of Halal (lawful) foods, which Allah has made lawful (meat of slaughtered eatable animals, milk products, fats, vegetables and fruits). The food (slaughtered cattle, eatable animals) of the people of the Scriptures (Jews and Christians) is lawful to you and yours is lawful to them.) (Qur'an 5: 4-5).

In the above verses, there is a general commandment given to all and sundry, Muslims, people of the Book (Jews and Christians) as well as the pagans (who were the creatures of Allah) concerning food and drinks. The Creator asks all His Creatures to follow His instruction and eat what is pure, clean, wholesome, nourishing and pleasant to the body. According to Doi (1984), all the qualities expected of food are beautifully summed up in the word 'Tayyib' meaning 'good'. This indicates that, mankind does not have much knowledge concerning his life except with the directive of the one that created everything. In this regards, the Qur'an says: "It is He (Allah) who created for you all things that are on earth, moreover, His design comprehends the heavens, for He gave order and perfection to the seven firmaments; and of all things He has perfect knowledge" (Qur'an 2:29). Most of the diseases encountered on earth today have something to do with what goes into the body. For instance, the world medical experts and nutritionists are of the opinion that cigarette smoking carries nicotine into the lungs and deposit a black object in it which hinders breathing (Oloyede et al, 2007). It was believed that other parts of the body can also be affected by these deposits and can develop into diseases like lung cancer, tuberculosis, cancer of the throat and heart diseases.

Also, swine is a dirty animal whose foul habits and coarse-feeding are well known. Moreover, eating the flesh of swine may become a cause of glandular fever and leprosy (Doi, 1984). Recent medical and scientific studies have also shown negative effect of alcohol (Sawari et al, 2015). Consuming alcohol acts as a depressant to the nervous system and it can cause shrinking of the brain which can affect the digestive system, cause high blood pressure and increase the risk of brain hemorrhage and strokes, or affect sleep patterns. According to (Sawari et al, 2015), Consuming alcohol even in small amount often leads to drunkenness and lowering of one's guard, which in turn leads to other bad behavior. Alcohol has also torn apart families and broken many lives and careers (Taofiq, 2013). A person may also contact disease from the consumption of blood and dead animals. This is why Islam made certain foods forbidden to guarantee the health of the living as well as protecting the human environment against pollution.

\section{Definition of Key Terms}

Food: Food is any substance consumed to provide nutritional value for an organism (Encyclopedia Brutanica). Food is usually of plant or animal origin, and contains essential nutrients such as carbohydrates, fats, proteins, vitamins, or minerals. The substance is ingested by an organism and assimilated by the organism's cells to provide energy, maintain life, or stimulate growth (Wikipedia). The main purpose of food is to maintain health and ensure healthy growth and development (Neslihan, 2018).

Health: The common perception of health is the absence of disease. The World Health Organization (1948) defines health as a state of complete physical, mental and social wellbeing and not merely an absence of disease or infirmity. It is on this note that Neslihan (2018), submits that, it is wrong to think that health means only the wellbeing of the body since a human being is comprised of a body, actions, social responses, senses, speech, mental faculties, and sexual characteristics all together, and the primary issue is the health of the whole. He then, adds that, health is the presence of complete wellbeing in all aspects of development in a human being.

Prohibition: Prohibition denotes all restrictive ordinances or anything that is not allowed according to the law (Al-Qaradawi, 1960). The Shari'ah has provided clear guidance in respect of lawful and the prohibited based on the teachings of the Qur'an and the Sunnah. Those things which are made unlawful are enumerated in details in the Qur'an: "He (Allah) has explained to you in in details what is forbidden to you" (Qur'an 6:119). Allah has fixed limits in respect of everything, and through the guidance of His Messenger. It is not 
any human being who decides what is lawful and unlawful, not even the Prophet through his own personal judgement. What is Halal (Lawful) is declared through the Qur'anic injunctions, and Muslims are asked to accept it as lawful. Likewise, nobody has an authority to declare any food, drink, dress or trade and business as haram (Prohibited). In this regards, the Qur'an says: "Do they have partners (with Allah) who have prescribed for them in religion that concerning which Allah has given no permission?" (Qur'an $42: 21)$.

Islam: Islam is an Arabic word which is derived from tri-consonantal root 'SLM' which means to surrender, to submit, to yield, to give oneself over (Mustapha and Balogun, 2012). Islam as an Arabic, rich in meaning word also connotes submission and obedience. Hence, the conventional definition of Islam as the religion of peace and submission denotes peace between man and his Creator, and peace between man and his fellow man. Peace is thus expected by Muslims to be implemented in practice as a realization of the fact that, one of God's attributes 'As-Salam means source of peace, and the adjective 'Muslim' means peaceful while the concluding words of the daily prayers in Islam are expressions of peace (Adigun W.F, 2012). One important dimension of the definition is the "commitment to submit and surrender to God so that one can live in peace". Peace (Salam) is achieve through active obedience to the revealed laws of God, for God is the Source of all peace. Commitment to Islam entails striving for peace through a struggle for justice, equality of opportunity, mutual caring and consideration for the rights of others, and continuous research and acquisition of knowledge for the protection and utilization of the resources of creation (Islam101, 2020).

\section{Foods That Are Prohibited in Islam}

Muslims are allowed to eat what is good (Qur'an 2:168). What is good entails food and drink that is identified as pure, clean, wholesome, nourishing and pleasing to taste. In Islam, everything is allowed (halal) except what has been specifically forbidden. Under the law, Muslims are enjoined to abstain from eating certain foods on health ground and in obedience to the commandment of Allah as epitomized in the Qur'an (Qur'an 2:173; 5:3; 5:90-91; 6:145; 16:115 e.t.c). It is on this note that the following foods and drinks are strictly prohibited (haram) in Islam:

$>$ Dead meat - Carrion

$>$ Blood

$>$ The flesh of swine (pork)

$>$ The meat of an animal that has been sacrificed to idols or animal dedicated to anyone other than Allah

$>$ Intoxicants

Dead meat- Carrion: Dead meat - Carrion refers to the animal that dies of itself (Malik, 1981). Qur'an categorizes dead animal to include: animal that dies as a result of disease, ill health or old age; animals that is beaten to death; animal that dies by falling from a height; animals which has been strangled to death like tying rope around its neck, or by suffocation etc; animal that dies as a result of being gored by the horns of another animal; animal that which has been (partly) eating by wild beasts (Qur'an 5: 4). Prophet Muhammad (SAW) was reported to have said: "Every beast of prey with canine teeth is forbidden to eat (Reported by Muslim). This hadith according to As-Sanani (2002), mentions a clear-cut and exhaustive indication of a standard stating that any flesh-eating beast of prey with canine teeth is forbidden to be eating. Similarly, any of the birds nibbling at its waste with the grip of its talons is forbidden. The reason behind prohibiting carrion as stated by Malik, (1981) and Qaradawi, (1960) is that, the death of the animal may have been caused by disease which may be harmful to human beings.

Blood: Allah says in the Quran, "Forbidden to you (for food) are ...blood...." (Qur'an 5: 3). During the age of ignorance, people used to cook and consume the large intestine of an animal with its blood poured over it. After the revelation of the Quran, the oozed blood was forbidden (Kanik, 2020). However, a little blood remaining in the animal's meat after it is slaughtered or the blood that has 
turned into meat in the liver are considered permissible. The reason for forbidding the consumption of blood is that, when restricted to the areas where blood should be, such as the heart and vessels, blood is necessary for life. However, eating blood is detrimental to both the body and spirit. On one hand, blood is a haven for microbial growth. All microbes after entering the body, concentrate in blood first. The white blood cells fight body toxicities by destroying bacteria and helping to remove unwanted material. When blood stops circulating in the body, white blood cells are destroyed. Thus, the microbes that have no opposition any more, tend to multiply rapidly. And when blood stops circulating in the body, it becomes the filthiest part of a human or animal's body. On the other hand, foods affect a man's temperament and conduct through influencing glands and their hormone production. Consuming blood thus leads to cruelty and hard-heartedness (Kanik, 2020).

Pork: Among the prohibited food in Islam is the flesh of wine. In this regard, Allah sasys in the Qur'an thus: "Forbidden to you (for food) are ...... and the flesh of swine..." (Qur'an 5:3). According to this verse, pork is considered prohibited as a whole so it becomes evident that pork is basically haram whether it is carrion or not. This is extended to such animals as dogs, cats, and monkeys. However, pork is specified because, the flesh of swine is produce from pig which relishes filth and offal, its meat is repugnant to persons of decent taste, moreover, medical research has proved that eating swine-flesh is injurious to health in all climates, especially hot ones. Scientific research has also that pork carries a deadly parasite (trichina), among others and no one can say what science may discover in the future which will shed more light on the wisdom of this prohibition (Qaradawi, 1960).

The meat of an animal that has been sacrificed to idols or animal dedicated to anyone other than Allah: The Qur'an says in this regards: "Forbidden to you are the flesh of dead....and that which has been dedicated to any other than Allah...." (Qur'an 5:3). This verse also refers to any animal that is slaughtered with the invocation of a name other than the of Allah. During the days of ignorance, the Arab polytheists when slaughtering an animal, would invoke the name of their idols like al- Lat or al- Uzza. Such a devotional act dedicated to someone other than Allah is prohibited. The above injunction implies that, if a halal animal is killed either in the name of any other than Allah, or, when Islamic rules have not been observed during the process, or, by disbelievers - it becomes prohibited to eat.

Intoxicants: Intoxicant is being described by the Qur'an as 'Khamr'. Khamr was used to refer to any drink or drug that could obscure the intellect (Adigun, 2015). Among the intoxicating liquids or drugs that could obscure the intellect includes: Wine, beer, hot drinks and drugs like optium, bhang, indian hemp, madras, marijuana and cocaine. All these fall under intoxicants, and intoxicants are forbidden in Islam. In this connection, the Qur' an says: “O you who believe! Do not approach prayer when you are drunken, until you know that which you utter." (Qur'an $4: 43$ ). In this verse, God refers to the fact that prayer becomes null and void when one is intoxicated. In another verse, it says: "They ask you concerning wine and gambling. Say: "In them is great sin, and some profit, for people; but the sin is greater than the profit." (Qur'an 2:219). In this verse, God introduced wine as having some benefit for people. Its benefits perhaps include the money made through its sale, minor health benefits as offered by various scientific studies, and the pleasure one gains as a result of drinking it. However, God has specified that, the harms it cause outweigh its benefits and thus forbidden. It is pertinent to note that, drinking intoxicants is naturally, morally, and intellectually harmful. Its negative physical effects include the disorder of the stomach, intestine, liver, lungs, nerves, blood vessels, heart, and the five senses (Kaniki, 2020).

Both past and modern physicians have written and presented statistics that indicate a variety of illnesses result from drinking wine. These include throat cancer, breast cancer, stroke, heart disease, and high blood pressure. Overall, it harms organs such as the brain, heart, liver, and pancreas. As for moral harms of drinking, intoxicating beverages, besides having negative effects on body also damage man's soul. It may lead to a person behaving without grace, or committing unintentional acts of insulting and harming others. They may commit crime or murder. They can divulge one's and others' secret and trample on human rules and sanctity, which form the basis of man's happiness. As for the intellectual harms of drinking intoxicating beverages, it dissipates one's wisdom, disrupts 
rational decision-making, and mars their perception and discretion. Drinking intoxicating beverages is the worst sin and evil because many evils are rooted in it.

\section{Conclusion and recommendation}

This paper has discussed the foods and drinks that are prohibited in Islam. The prohibition is a divine intervention to safeguard the interest of man. The Qur'an describes these forbidden things as bad, impure and harmful as they have negative impact on people's health and wealth. It is therefore recommended that, Muslims should follow the dictates of Islam regarding food prohibitions in order to live a healthy life.

\section{References}

Adigun, W.F. (2012). "Peace, National Security and Sustainable Development: An Islamic Perspective”. National Security and Sustainable Development: Prospects and Challenges. Zonal Journal of Women in Colleges of Education (ZOJOWICE) Vol. 1 No 1.

Adigun, W.F. (2015). "Islamic Ethics and Morality from Selected Suwar of Al-Qur'an”. Islamic Studies. A publication of College of Education, Ikere-Ekiti. Vol.4

As-Sanani M. I. (2002). Bulugh Al-Maram-Attainment of the objective according to Evidence of the Ordinances. Riyadh, Darussalam.

Doi, A.I (1984). Shari'ah: The Islamic Law. United Kingdom. Ta-Ha Publishers.

Islam101 (2020). Islam: A brief Introduction.www.islam101.com

Kaniki, J.N (2020). Reasons for the Prohibition of Specific Foods in the Qur'an. http://www.al.islam.org Oloyede et al (2007) Exam Focus Islamic Studies for WASSCE/NECO, Ibadan University Press.

Malik, S.H (1981). Ya Sin Wal-Qur’an. Ilesa. Ilesanmi Press \& Son LTD.

Mustapha, A.R and Balogun, H.O (2012). Leadership in Islam. Ado. Deen-Lat Publishers

Neslihan, N.T. (2018). Health, Hygiene and First Aid. Nigeria. EY ERKAM

Qaradawi, Y. (1989). The Lawful and Prohibited in Islam. Lagos. Al-Waseelah.

Reima, Y. Shakeis (ed.) (2006) 500 Questions and Answers on Islamic Jurisprudence, Egypt. Dar Al-Manarah.

Salih, F. (2009). A summary of Islamic Jurisprudence. Al-Maiman Publishing House.

Sawari, S.S. et al (2015). Evidence Based Review on the Effect of Islamic Dietry Law towards Human Development. Mediterranean Journal of Social Sciences. Rome- Italy. MCSER

Tawfiq, I. (2013). Why is Alcohol Forbidden?.http://www.onislam.net/English/ask-about-islam/ethics-and-values/muslim-character. 